\title{
Work Enjoyment dan Organizational Citizenship Behavior pada Karyawan PT. Petrokimia Kayaku
}

\author{
Septiyan Nugroho ${ }^{1}$ dan Ni Wayan Sukmawati Puspitadewi \\ Program Studi Psikologi Universitas Negeri Surabaya
}

\begin{abstract}
Organizational Citizenship Behavior is one form of behavior of employeesthat shows the tendency to be cooperative in an organization.This research holds a purpose to test the correlation between Work Enjoyment and Organizational Citizenship Behavior in PT Petrokimia Kayaku Gresik. This research used quantitative approach which focuses on correlational research design. The number of population in this research was 170 people and the samples obtained were 63 people that was selected using random sampling technique. Questionnaire was chosen as the way to collect the data needed in this research. There were two kinds of questionnaires whichwere developed by the researcher to determine Organizational Citizenship Behavior's scale and workenjoyment's scale. The data analysis used was product moment's correlation. According to the data analysis, there is a significant correlation between work enjoyment and Organizational Citizenship Behavior, with the correlation coefficient 0,861 and $p=0,000$ that indicates high and significant correlation.
\end{abstract}

\section{Keywords: Work enjoyment, organizational citizenship behavior}

\begin{abstract}
Abstrak: Organizational Citizenship Behavior merupakan salah satu bentuk perilaku dari karyawan yang menunjukkan kecenderungan untuk koperatif dalam suatu organisasi. Penelitian ini bertujuan untuk mengetahui hubungan antara Work Enjoyment dengan perilaku Organizational Citizenship Behavior pada Karyawan PT Petrokimia Kayaku Gresik. Penelitian dilakasanakan dengan pendekatan kuantitatif dengan rancangan penelitian korelasional. Jumlah populasi pada penelitian ini sebesar 170 orang, sampel diambil dengan menggunakan random sampling sehingga didapat jumlah sampel sebanyak 63 orang. Pengambilan data pada penelitian ini menggunakan kuesioner yang dikembangkan oleh peneliti yaitu skala Organizational Citizenship Behavior dan skala work enjoyment. Analisis data menggunakan korelasi product moment. Berdasarkan hasil analisis data ada hubungan yang signifikan antara work enjoyment dengan Organizational Citizenship Behavior dengan koefisien korelasi sebesar 0,861 dengan $\mathrm{p}=0,000$ hubungan tinggi dan signifikan.
\end{abstract}

\section{Kata Kunci: Work enjoyment, organizational citizenship behavior}

Globalisasi ditandai dengan terjadinya perubahan-perubahan pesat pada kondisi ekonomi dan bidang lain menyebabkan munculnya sejumlah tuntutan yang tidak bisa ditawar bagi para pelaku ekonomi maupun industri. Salah satu tuntutan terbesar adalah bagaimana organisasi secara responsif menanggapi perubahan-perubahan yang terjadi. Perubahan eksternal seharusnya juga diikuti oleh perubahan internal organisasi, agar dapat beradaptasi terhadap lingkungannya. Sumber Daya Manusia (SDM) merupakan faktor terpenting dalam usaha pencapaian keber-hasilan dalam menghadapi segala perubahan yang terjadi (Wahyuddin, 2007).

Korespondensi tentang artikel ini dapat dialamatkan kepada Septiyan Nugroho melalui e-mail: septiyanugroho@gmail.com. 
Keunggulan suatu organisasi dapat dicapai dengan meningkatkan kinerja individual karyawan. Kinerja individu tersebut akan berpengaruh pada kinerja tim dan pada akhirnya akan berpengaruh pada kinerja organisasi secara keseluruhan (Atkinson \& Laura, 2011). Kontribusi karyawan terhadap organisasi akan semakin tinggi bila organisasi dapat memberikan apa yang diinginkan karyawan. Menurut Borman dan Motowidlo (1993) manajemen organisasi yang profesional akan memperhatikan pengelolaan Sumber Daya Manusia yang merupakan aset penting dan berharga untuk mewujudkan efektivitas organisasi, serta mencapai tujuan organisasi dalam membangun performa yang tinggi.

Salah satu perilaku penting dalam efektivitas organisasi adalah Organizational Citizenship Behavior, hal ini seperti yang dikemukakan oleh Katz (1964:132) yang mengidentifikasi adanya tiga kategori perilaku yang penting bagi efektivitas organisasi, yaitu: (1) individu harus masuk ke dalam dan tinggal dalam suatu organisasi, (2) mereka harus menyelesaikan peran khusus dalam suatu pekerjaan tertentu, dan (3) mereka harus terikat pada aktivitas yang inovatif melebihi persepsi perannya. Kategori yang ketiga itulah yang disebut sebagai Organizational Citizenship Behavior.

Organizational Citizenship

Behavior didefinisikan sebagai kontribusi individu yang mendalam melebihi tuntutan peran kerja. Organizational Citizenship Behavior direfleksikan melalui perilaku karyawan yang kooperatif, suka menolong, perhatian, dan bersungguh-sungguh. Perilaku yang mencerminkan kepatuhan dalam organisasi dapat ditunjukkan dengan ketepatan waktu masuk dan pulang kerja, serta ketepatan penyelesaian tugas. Oleh karena itu, dapat dikatakan Organizational Citizenship Behavior sangat dipengaruhi oleh individu itu sendiri.
Penelitian tentang Organizational Citizenship Behavior dengan kinerja telah dilakukan oleh Bachrach dkk (2001) yang menemukan bahwa pekerja dengan Organizational Citizenship Behavior akan membuat tim atau organisasi kerjanya lebih efektif. Contoh pekerja yang menunjukkan perilaku menolong, seperti berbagi keahlian tertentu dengan para pekerja lain dan mencegah munculnya permasalahan, memberikan beberapa saran yang membangun untuk perusahaan yang mungkin dapat dilakukan untuk meningkatkan kinerja dan juga untuk menyampaikan apa yang mereka pikirkan bagi kebaikan perusahaan.

Karyawan yang tidak memiliki Organizational Citizenship Behavior adalah karyawan yang menunjukkan perilaku tidak membantu pekerjaan rekan kerja ketika pekerjaannya selesai, bermalas-malasan pada saat jam kerja dan tidak patuh dengan prosedur maupun instruksi organisasi. Beberapa karyawan dalam suatu organisasi ada yang menunjukkan perilaku Organizational Citizenship Behavior dan ada pula yang tidak berperilaku demikian.

Penting bagi perusahaan untuk dapat meningkatkan Organizational Citizenship Behavior pada karyawan, maka dari itu sangat penting bagi perusahaan tersebut untuk mengetahui apa yang dapat menyebabkan munculnya atau meningkatnya Organizational Citizenship Behavior. Menurut Siders, dkk (2001:570) perilaku Organizational Citizenship Behavior dipengaruhi oleh dua faktor utama, yaitu faktor yang berasaldari luar karyawan (eksternal) seperti sistem manajemen, sistem kepemimpinandan budaya perusahaan, sedangkan faktor yang berasal dari dalam diri karyawan (internal) seperti moral, rasa puas dan sikap positif.

Sikap positif dalam organisasi sebagai faktor internal organisasi sering dimungkinkan mendahului Organizational 
Citizenship Behavior dalam organisasi, dimana sikap positif merupakan salah satu aspek dimensi dari Work Enjoyment (Bakker, 2007:400). Work Enjoyment dalam dunia kerja merupakan suatu rasa untuk menikmati pekerjaan, yang akan mendorong semangat bekerja dengan penuh tanggung jawab pada setiap karyawan. Karyawan yang dapat memperlihatkan semangat kerja akan memiliki keterlibatan positif terhadap pekerjaan mereka. Hal ini berhubungan dengan motivasi dan dedikasi karyawan terhadap pekerjaanya (Schaufeli dkk, 2008).

Ada berbagai macam hambatan external yang terjadi dalam dunia kerja, contohnya sabotase, persaingan, kurangnya fasilitas dan modal, tekanan dari atasan dan lain-lain. Hambatan-hambatan tersebut terkadang dapat mempengaruhi kinerja karyawan. Karyawan yang menikmati pekerjaannya akan memandang hambatan tersebut sebagai suatu tantangan. Langkah yang dapat ditempuh dalam menghadapi tantangan adalah berpikir positif. Karyawan akan melihat tantangan sebagai jalan untuk meningkatkan kualitas diri, dengan begitu suatu tantangan diharapkan tidak akan menghambat kinerja. Sikap ini akan berbeda apabila hambatan tersebut menimpa karyawan yang tidak menikmati pekerjaannya.

Karyawan yang tidak menikmati pekerjaannya, apabila mendapat hambatan dalam kerjanya akan merasa mudah putus asa dan akan cenderung merasa jenuh juga merasa tidak puas dengan pekerjaannya tersebut (Gibson dkk., 1996). Karyawan yang tidak menikmati pekerjaannya akan lebih banyak mengeluh dengan apa yang menimpanya, daripada bersyukur dan mencoba untuk menjadikan hambatan sebagai tantangan yang dapat meningkatkan kualitas dirinya.

Adanya Work Enjoyment yang timbul dari diri setiap karyawan di dalam perusahaan, tidak luput dari peranan para karyawan itu sendiri sebagai sumber daya manusia yang selalu bisa diandalkan kinerjanya oleh perusahaan, yaitu untuk berperan aktif dalam pencapaian tujuan perusahaan. Perusahaan yang menjunjung tinggi kinerja para karyawannya, akan memberikan suatu pengekspresian diri yang bersifat fleksibel dalam memproses dan menyelesaikan suatu perkerjaan, dengan cara yang tidak terlalu terikat dan cenderung bebas tersebut akan memberikan dampak yang baik bagi para karyawan, yaitu rasa senang, nyaman dan bisa menikmati pekerjaannya (Atkinson \& Laura, 2011). Sikap dan kebijakan perusahaan yang bisa membuat karyawannya merasa senang dalam bekerja tersebut akan dapat menumbuhkan rasa tulus dengan antusias melakukan pekerjaan tanpa harus menunggu perintah dan juga kendali dari perusahaan, sehingga akan menciptakan suatu budaya saling bekerja sama dalam perusahaan untuk memberikan tujuan yang baik bagi perusahaan itu sendiri.

Rasa nyaman di tempat kerja dan juga dalam melakukan pekerjaan dapat terwujud apabila setiap karyawan yang ada didalam suatu perusahaan bisa menjalin hubungan baik dengan sesama rekan kerjanya maupun dengan atasannya. Hubungan tersebut memiliki nilai positif dan tidak memberikan suatu dampak yang buruk, sehingga akan menimbulkan hubungan timbal balik yang positif pula, yaitu dengan perilaku dimana karyawan akan saling membantu meskipun tanpa diminta dan hal itu diluar tanggung jawab formal mereka dalam organisasi (Fox, 1974). Work Enjoyment dan Organizational Citizenship Behavior akan muncul dalam setiap diri karyawan apabila hal tersebut diterapkan dalam perusahaan.

Berdasarkan keterangan dari Kepala Regu SDM, juga selaku pembimbing penelitian, menjelaskan bahwa pada 
pekerja lapangan dituntut bekerja sesuai dengan tugas formal yang sudah ditentukan, karena pekerjaan dilapangan menuntut kualitas kinerja yang tinggi sesuai dengan bidang keahlian masingmasing pekerja. Sistem kerja yang demikian menunjukkan bahwa perilaku Organizational Citizenship Behavior tidak muncul pada pekerja lapangan, sehingga penelitian diarahkan pada karyawan saja.

Pada kenyataan di PT Petrokimia Kayaku menunjukkan beberapa fenomena, dengan adanya tingkah laku karyawan PT Petrokimia Kayaku yang kurang aktif dalam berinisiatif. Kurang memiliki inisiatif untuk membantu karyawan lainnya dan enggan melakukan pekerjaan diluar tugas formal mereka. Contohnya karyawan yang tidur pada saat jam kerja, menolak pada saat ada karyawan lain yang meminta tolong dan lebih mementingkan pekerjaan mereka masing-masing. Perilaku yang tidak mencerminkan Organizational Citizenship Behavior pada diri karyawan dapat memberikan dampak yang tidak baik bagi karyawan sendiri maupun bagi kinerja tim dalam perusahaan.

Fenomena yang muncul pada karyawan PT Petrokimia Kayaku berdasarkan keterangan dari Kepala Departemen SDM, hampir semua karyawan yang baru dipindah divisi dari bagian lapangan menjadi karyawan bagian kantor dan juga regulasi dari pelaksana menjadi Kepala Seksi, mengeluh terbebani dengan pekerjaannya. Adanya tuntutan kerja yang harus memenuhi target perusahaan dengan deadline waktu tertentu, menangani banyak dokumen dan laporan perusahaan juga memimpin banyak bawahan. Karyawan tersebut sering melakukan kesalahan, sehingga menghasilkan kinerja yang kurang maksimal bagi perusahaan. Hal itulah yang membuat karyawan tersebut kurang merasakan Work Enjoyment dalam melakukan pekerjaannya.
Pada kasus lain, terdapat seorang karyawan muda yang mengeluh karena sikap atasan yang membandingkan hasil kerja karyawan tersebut dengan karyawan muda lainnya, dengan alasan kinerja karyawan yang kurang maksimal, lamban dan menghasilkan laporan perusahaan yang kurang baik. Menurut karyawan tersebut pekerjaan yang dilakukan sudah maksimal dan sebagai karyawan muda masih perlu arahan dari atasan. Hal ini juga dapat menimbulkan Work Enjoyment pada karyawan menurun, karena tekanan dari atasan.

Berdasarkan latar belakang masalah diatas, dengan adanya Work Enjoyment yang menurun dan juga kurangnya Organizational Citizenship Behavior pada karyawan telah menggugah minat peneliti melakukan penelitian dengan melihat hubungan antara Work Enjoyment dengan perilaku Organizational Citizenship Behavior pada karyawan PT Petrokimia Kayaku Gresik. Peneliti melakukan penelitian di PT Petrokimia Kayaku Gresik ini dikarenakan PT Petrokimia Kayaku Gresik merupakan produsen Pestisida terkemuka di Indonesia. Join venture dari PT Petrokimia Gresik (Persero) dari Indonesia dengan Mitsubishi Corporation dan Nippon Kayaku Co. Ltd. dari Jepang yang menjunjung tinggi kedisiplinan.

Para karyawan dalam perusahaan tersebut juga dituntut bekerja dalam tim yang menjunjung tinggi kerja sama yang solid demi tercapainya tujuan yang positif dalam perusahaan, sehingga dengan mengetahui apakah karyawan PT Petrokimia Kayaku Gresik telah melakukan Work Enjoyment dan Organizational Citizenship Behavior tentu akan mendatangkan dampak yang baik bagi para karyawan dan juga perusahaan itu sendiri. Tujuan dalam penelitian ini adalah "untuk mengetahui hubungan antara Work Enjoyment dengan perilaku Organizational 
Citizenship Behavior pada karyawan PT Petrokimia Kayaku Gresik."

\section{Metode}

Penelitian ini merupakan penelitian kuantitatif yang telah memenuhi kaidahkaidah ilmiah yaitu konkrit atau empirik, obyektif, terukur, rasional, serta sistematis statistik. (Sugiyono, 2011:125). Penelitian ini menggunakan rancangan penelitian korelasional menggunakan dua variabel, yaitu variabel bebas (X) Work Enjoyment dan variabel terikat (Y) Organizational Citizenship Behavior. Teknik analisis data menggunakan uji korelasi product moment.

Populasi yang digunakan dalam penelitian adalah karyawan tetap PT Petrokimia Kayaku Gresik yang berjumlah 170 orang karyawan,. Jumlah sampel sebanyak 63 orang yang diambil menggunakan teknik random sampling.

Penelitian ini menggunakan kuesioner untuk menguji validitas dan instrumen penelitian skala psikologis dalam bentuk skala Likert yang menggunakan empat alternatif jawaban yaitu; (1) STS untuk jawaban sangat tidak setuju, (2) TS untuk jawaban tidak setuju, (3) S untuk jawaban setuju, dan (4) SS untuk jawaban sangat setuju. Suatu tes atau instrumen pengukur dapat dikatakan mempunyai validitas yang tinggi apabila alat tersebut menjalankan fungsi ukurnya, atau memberikan hasil ukur, yang sesuai dengan maksud dilakukannya pengukuran tersebut (Azwar, 2010).

Dalam uji validitas ini, tryout dilakukan 1 kali putaran dengan jumlah aitem sebelum uji coba skala work enjoyment 36 aitem. Skala organizational citizenship behavior sebelum uji coba terdapat 64 aitem. Setelah melaksanakan uji coba, maka langkah selanjutnya yang dilakukan adalah tabulasi data untuk mengetahui validitas dan reliabilitas skala yang diuji cobakan. Setelah dilakukan tabulasi diketahui validitas dan reliabilitas alat ukur dan didapatkan aitem yang dinyatakan gugur. Skala work enjoyment memiliki aitem valid 34 aitem, dan aitem gugur sebanyak 2 aitem, sedangkan skala organizational citizenship behavior memiliki aitem valid sebanyak 46 aitem, dan aitem gugur sebanyak 18 aitem.

Hasil uji reliabilitas diatas menunjukan bahwa nilai reliabilitas skala work enjoyment adalah sebesar 0,923, angka tersebut menunjukan bahwa skala work enjoyment memiliki reliabilitas yang tinggi. Hasil uji reliabilitas diatas menunjukan bahwa nilai reliabilitas skala organizational citizenship behavior adalah sebesar 0,960, angka tersebut menunjukan bahwa skala organizational citizenship behavior memiliki reliabilitas yang tinggi.

\section{Hasil dan Pembahasan}

Uji asumsi yang terdiri dari uji normalitas dan uji linieritas dilakukan sebelum dilakukan uji hipótesis. Uji normalitas ini dilakukan dengan menggunakan uji One Sample Kolmogorov -Smirnov. Berdasarkan hasil uji normlitas dapat diketahui bahwa nilai signifikansi dari variabel Work Enjoyment sebesar 0,692, variabel Organizational Citizenship Behavior sebesar 0,428, sehingga data memiliki distribusi data yang normal karena nilai signifikansinya lebih dari 0,05.

Uji linieritas dilakukan dengan menggunakan analisis statistik uji $F$. Berdasarkan hasil uji linearitas didapatkan hasil antara Work Enjoyment dan Organizational Citizenship Behavior masingmasing memiliki nilai signifikansi 0,000 sehingga hubungan linier.

Hasil uji hipotesis dapat diketahui bahwa variabel Work Enjoyment memiliki hubungan yang positif dan signifikan terhadap perilaku Organizational Citizenship Behavior dengan nilai r sebesar 0,861 yang berarti memiliki hubungan yang 
sangat tinggi dan nilai signifikansi yang diperoleh adalah 0,000 , Ini berarti nilai signifikansinya dibawah 0,05 sehingga kedua variabel tersebut memiliki hubungan yang signifikan.

Hasil uji hipotesis yang menunjukkan bahwa terdapat hubungan antara Work Enjoyment dan Organizational Citizenship Behavior pada karyawan PT Petrokimia Kayaku Gresik. Hasil yang didapatkan antara variabel Work Enjoyment dan Organizational Citizenship Behavior memiliki koefisien korelasi sebesar 0,861 yang berarti hubungan antara variabel Work Enjoyment dan Organizational Citizenship Behavior sangat kuat. Hubungan tersebut bersifat positif yang berarti hubungan berjalan searah yang dapat disimpulkan jika Work Enjoyment cenderung positif maka akan memiliki Organizational Citizenship Behavior yang tinggi, sebaliknya jika work enjoyment cenderung negatif maka Organizational Citizenship Behavior juga akan rendah.

Berdasarkan nilai $r=0,861$ ini menunjukan kekuatan hubungan Work Enjoyment dengan perilaku Organizational Citizenship Behavior sebesar $86,1 \%$ pada karyawan PT. Petrokimia Kayaku, sedangkan sisanya $13,9 \%$ dipengaruhi oleh faktor lain yang tidak di teliti. Adapun faktor selain Work Enjoyment yang dapat mempengaruhi seseorang melakukan perilaku Organizational Citizenship Behavior. Menurut Novliadi (2007:12) yang pertama budaya organisasi, dimana budaya organisasi yang positif akan mendukung karyawan melakukan Organizational Citizenship Behavior dan membuat karyawan merasa lebih ingin melakukan pekerjaan melebihi apa yang telah menjadi tanggung jawab pekerjaannya. Kedua adalah persepsi terhadap dukungan organisasi, dimana karyawan akan merasa bahwa organisasi mendukung penuh karyawan sehingga karyawan akan memberikan timbal balik dalam perilaku Organizational Citizenship Behavior. Ketiga adalah kualitas interaksi atasan-bawahan, dimana jika hubungan atasan-bawahan berjalan baik dan atasan mampu memotivasi dan memberi contoh kepada bawahannya tentu hal itu dapat memicu timbulnya Organizational Citizenship Behavior karyawan. Keempat adalah kepribadian dan suasana hati, karyawan yang suasana hatinya baik atau positif akan cenderung berinteraksi yang baik dengan lingkungannya, sehingga karyawan tersebut akan lebih meningkatkan peluangnya untuk membantu rekan kerja lainnya. Kelima adalah masa kerja, karyawan yang telah lama bekerja pada suatu kantor akan lebih merasa dekat dan saling memiliki.

Penelitian ini sesuai dengan pendapat dari Podsakoff dkk. (2000) yang menemukan bahwa karyawan yang terpuaskan dengan work enjoyment akan cenderung memiliki Organizational Citizenship Behavior yang tinggi terhadap organisasi. Hal ini ditandai dengan adanya kontribusi individu yang mendalam melebihi tuntutan peran kerja, yang direfleksikan melalui sikap karyawan yang kooperatif dan nyaman dalam menyelesaikan pekerjaan. Karyawan yang memiliki Organizational Citizenship Behavior akan lebih termotivasi dalam menjalani tugas di dalam perusahaan. Sebaliknya karyawan yang merasakan keti-dakpuasan dengan Work Enjoyment cenderung akan mengurangi Organ-izational Citizenship Behavior terhadap perusahaan.

Penelitian lain yang mendukung hasil penelitian ini dilaksanakan oleh Purba \& Seniati (2004) yang melaporkan tentang pentingnya perilaku Organizational Citizenship Behavior di Indonesia karena perubahan dinamika kerja pada organisasiorganisasi yang dulunya bekerja secara individu sekarang bergeser menjadi bekerja secara tim. Tidak hanya itu, perubahan yang terjadi di Indonesia salah satunya juga 
maraknya downsizing (perampingan organisasi dengan mengurangi jumlah tenaga kerja) yang berdampak pada perubahan tugas dan kewajiban karyawan yang semakin banyak, sehingga organisasi tersebut akan bergantung dengan karyawan yang masih tinggal untuk bekerja melebihi apa yang telah ditugaskan pada mereka. Tujuan penelitian ini adalah untuk melihat anteseden Organizational Citizenship Behavior pada subyek karyawan industri di Indonesia, dari analisis penelitian tersebut diketahui bahwa Work Enjoyment berpengaruh cukup besar terhadap Organizational Citizenship Behavior di Indonesia.

Hasil dari penelitian ini menunjukkan jika karyawan melakukan Work Enjoyment saat bekerja, maka karyawan tersebut memiliki kecenderungan melakukan perilaku Organizational Citizenship Behavior. Work Enjoyment dapat tercipta jika suasana di tempat kerja juga mendukung terciptanya Work Enjoyment. Lingkungan kerja yang kondusif dan nyaman akan membuat karyawan menjadi tenang dan enjoy saat bekerja. Jadi bisa dikatakan apabila karyawan memiliki Work Enjoyment maka, karyawan tersebut juga akan cenderung melakukan Organizational Citizenship Behavior. Karyawan tersebut akan lebih mudah berinteraksi dengan lingkungan kerjanya, dengan sukarela membantu teman yang mengalami kesulitan meskipun itu bukan menjadi tanggung jawabnya sehingga target-target kerja organisasi dapat terpenuhi. Hal ini akan menguntungkan organisasi karena tingkat keefektifan organisasi akan meningkat.

\section{Simpulan dan Saran}

Berdasarkan hasil penelitian dapat disimpulkan bahwa terdapat hubungan antara Work Enjoyment dengan Organizational Citizenship Behavior. Work enjoyment dengan Organizational
Citizenship Behavior memiliki nilai koefisien korelasi 0,861 artinya memiliki hubungan signifikan dan sangat tinggi, semakin tinggi Work Enjoyment dan maka semakin tinggi Organizational Citizenship Behavior.

Berdasarkan simpulan tersebut, maka dapat dikemukakan beberapa saran. Pertama, perusahaan perlu meningkatkan motivasi intrinsik karyawan dalam pekerjaan mereka. Motivasi intrinsik tersebut dapat ditingkatkan misalnya dengan menciptakan tata ruang kerja yang rapi dan bersih serta suasana kerja yang kondusif hingga dapat menimbulkan perasaan nyaman dan betah (work enjoyment) di tempat kerja. Penataan ruang kerja yang nyaman, keadaan sarana dan fasilitas yang ada di PT Petrokimia Kayaku Gresik juga dapat mendorong tingkat karyawannya. Rasa kekeluargaan yang lebih erat juga akan menjadikan suasana perusahaan lebih nyaman sehingga karyawan lebih bisa menikmati pekerjaannya.

Selain itu, pemimpin yang demokratis, bijaksana, adil, dan dekat dengan para karyawannya akan menjadikan karyawan lebih nyaman dalam bekerja, karena pemimpin yang demokratis dapat memberikan bimbingan yang lebih efisien kepada para karyawannya, pemimpin seperti itu dapat mengkoordinasikan pekerjaan kepada karyawannya dan menekankan pada karyawannya untuk lebih bertanggung jawab pada pekerjaannya dan membimbing untuk lebih menganut nilainilai yang ada dalam visi dan tujuan dari perusahaan tersebut.

Kedua, penelitian ini hanya menekankan pada variabel work enjoyment saja, sehingga tidak semua faktor yang mempengaruhi organizational citizenship behavior dapat diungkap. Penelitian selanjutnya diharapkan dapat mengungkap beberapa variabel lain yang menjadi faktor penentu tersebut. 


\section{Daftar Pustaka}

Atkinson, C, \& Laura, H. (2011). Flexible Working and Happiness in The NHS. Inggris : University of Bradford School of Management.

Bachrach, D. G., Bendoly, E., \& Podsakoff, P.M. (2001). Attributions of the Causes of Group Performance as an Alternative Explanation of the Relationship Between Organizational Citizenship Behavior and Organizational Performance. Journal of Applied Psychology, (online),86,1285-1293. http://www.researchgate. net/publication/pdf, diakses 19 Mei 2013.

Bakker, A., B. (2007). The work-related flow inventory: Construction and initial validation of the WOLF. Journal of Vocational Behavior. (online), 72 400-414. http://www.beanmanaged.eu/pdf/ articles/arnoldbakker/article_arnold _bakker_165.pdf, diakses 19 Mei 2013.

Borman, W. C., \& Motowidlo, S. J. (1993). Expanding the criterion domain to include elements of contextual performance. In N. Schmitt, W. C. Borman, \& Associates (Eds.), Personnel selection in organizations (online) 71-98. San Fransisco. CA: Jossey-Bass. http://books.google.com/books?isbn $=0826195636$, diakses 19 Mei 2013.

Fox, W. (1974). The working of a Commodity Agreement. Mineng Journal Books. (online).London.http://books.googl e.com/books?isbn=1847205461, diakses 19 Mei 2013.

Gibson, J. L., Ivancevich, J. M., \& Donnelly, J. H. (1996). Perilaku Organisasi: Struktur dan Proses.
Terjemahan Djarkasih . Jakarta: Erlangga.

Katz, D. (1964). Motivational Basis of Organizational Behavior. Behavioral Science, (online), 9 (2) : 131-146.

http://onlinelibrary.wiley.com/doi/ 10.1002/bs.3830090206/references, diakses 19 Mei 2013.

Novliadi, F. (2007). Organization Citizenship Behavior Karyawan Ditinjau Dari Persepsi Terhadap Kualitas Interaksi Atasan-Bawahan dan Persepsi Terhadap Dukungan Organisasi. Skripsi. Tidak Dipublikasikan. Medan: USU

Podsakoff, P. M., McKenzie, S. B., Paine. J. B., \& Bachrach, D. G. (2000). Organizational Citizenship Behavior : A Critical Review of The Theorical and Empirical Literature and Suggestionsfor Future Research. Journal of Management. (online), 26 (03): 513-563. http://myweb.usf.edu..pdf, diakses 19 Mei 2013.

Purba, D. E., \& Seniati, A. N. L. (2004). Pengaruh Kepribadian dan Komitmen Organisasi Terhadap Organizational Citizenship Behavior. Jakarta : Universitas Indonesia.

Schaufeli, W. B., Leiter, M. P., \& Maslach, C. (2009). Burnout 35 years of research and practice. Journal of Career Development International, (Online), 14(3), 204-220. http://www.emerald insight.com/,diakses 19 Mei 2013.

Siders, M. A., George, G., \& Dharwadkar, R. (2001). The relationship of internal and external commitment foci to objective job performance measures. Academy of Management Journal, (online), 44 (3),570-579. 
http://www.aom.pace.edu/amj

/June2001/siders.pdf, diakses Mei 2013.

Sugiyono. (2011). Statistika untuk Penelitian. Bandung: Penerbit Alfabeta.
Wahyuddin, P. (2007). Pengaruh FaktorFaktor Kepuasan Kerja Terhadap Kinerja Karyawan. Skripsi. Tidak dipublikasikan. Surakarta: Universitas Muhammadiyah. 